\title{
Intramolecular Capture of Pummerer Reaction Intermediates by an Aromatic Nucleophile: Selective Construction of 1,4-Benzothiazine and Indole Ring Systems
}

\author{
Yoshie Horiguchi, Akihiro Sonobe, Toshiaki Saitoh, Jun Toda, and Takehiro SAno* \\ Showa Pharmaceutical University, 3-3165 Higashi-tamagawagakuen, Machida, Tokyo 194-8543, Japan. \\ Received March 26, 2001; accepted June 5, 2001.
}

The simple alkyl sulfoxide 6 carrying two aromatic nucleophiles, when treated with trifluoroacetic anhydride at room temperature (Pummerer reaction conditions), underwent an intramolecular aromatic sulfenylation of the 6-exo-tet process in an exclusive manner to yield two regioisomeric 1,4-benzothiazine derivatives, 8 and 9. On the other hand, a similar reaction of the $\alpha$-acyl sulfoxide 7 , possessing identical aromatic nucleophiles, caused an intramolecular aromatic alkylation of the 5-exo-trig process to produce the 3-oxo-indole derivative 14 in a quantitative yield. These results demonstrate that the construction of 1,4-benzothiazine and indole ring systems can be achieved in a selective manner by proper choice of the sulfoxide side chain.

Key words Pummerer reaction; sulfoxide; cyclization; sulfenylation; 1,4-benzothiazine; indole

The Pummerer reaction proceeds from sulfoxide to a product via a sulfonium ion (II) which reacts with a nucleophile at the carbon (alkylation). ${ }^{1)}$ In the interrupted Pummerer reaction, ${ }^{2)}$ an acylated sulfoxide intermediate (I) undergoes reaction with the nucleophile at the sulfur (sulfenylation), leading to unexpected products under Pummerer reaction conditions.

The finding that the sulfonium ions may serve as electrophiles in electrophilic substitution has generally extended to the synthetic range of the Pummerer reaction. ${ }^{1)}$ Thus, both intra- ${ }^{3)}$ and intermolecular ${ }^{4}$ versions of the process have been used to prepare a wide range of compounds. Recently, Padwa et al. emphasized in their review ${ }^{5)}$ that $\alpha$-acyl sulfonium ions generated from $\alpha$-acyl sulfoxides are highly reactive and can trap various nucleophiles involving carbon $\pi$ bonds. In particular, they describe that the aromatic cyclization reactions in which an aromatic nuclei acts as the carbon nucleophile are useful to construct various complex polycyclic ring systems. More recently, we have demonstrated that simple alkyl sulfonium ions not having an $\alpha$-acyl function are also able to induce aromatic cyclization under mild reaction conditions. ${ }^{6}$ ) This approach provides a highly effective and convenient technique for preparing a variety of aromatic condensed $N$-heterocyles. ${ }^{6,7)}$

During the course of the investigations, we observed that alkyl sulfoxides, if the aromatic nucleophile is highly electron-rich, predominantly undergo intramolecular sulfenylation (interrupted Pummerer reaction), while if the aromatic nucleophile is not highly electron-rich, the sulfoxides undergo intramolecular alkylation (Pummerer reaction) in an exclusive manner. ${ }^{7 b, g)}$ Before our findings, Bates et al. had reported that a sulfoxide possessing a highly electron rich pyrrole as the nucleophile exclusively underwent intramolecular sulfenylation, when the side chain of an alkyl aryl sulfoxide was a simple alkyl, $\left.{ }^{2,8}\right)$ while the reaction of a sulfoxide whose alkyl side chain contained an electron-withdrawing group on the $\alpha$-carbon, induced aromatic intramolecular alkylation in an exclusive manner. ${ }^{9)}$ These facts suggest that the reaction path can be diverted in one direction or the other by the proper choice of either a sulfoxide side chain or nucleophilic aromatic moiety.

In this paper we treat the Pummerer reactions of two different types of sulfoxides, a simple alkyl sulfoxide (A) and an $\alpha$-acyl sulfoxide (B) carrying two identical aromatic nucleophiles, with the expectation that the reactions should disclose what chemical properties of the sulfoxide side chains can control two different cyclization reactions. At the same time, the sulfoxides, because of having two aromatic nuclei of similar nucleophilicity, could conceivably cause two additional cyclizations, as shown in Chart 2: 1) Aromatic sulfenylation to benzothiazine, 2) aromatic sulfenylation to benzothiazepine, 3) aromatic alkylation to indole, and 4) aromatic alkylation to isoquinoline. Thus, this investigation may reveal the preference of the ring size formed by each cyclization.

\section{Results and Discussion}

The alkyl sulfoxide $\mathbf{6}$ and the $\alpha$-acyl sulfoxide 7 were prepared from $m$-anisidine $\mathbf{1}$ and piperonal $\mathbf{2}$ in excellent overall yields, as follows. Condensation of $\mathbf{1}$ with $\mathbf{2}$ in titanium

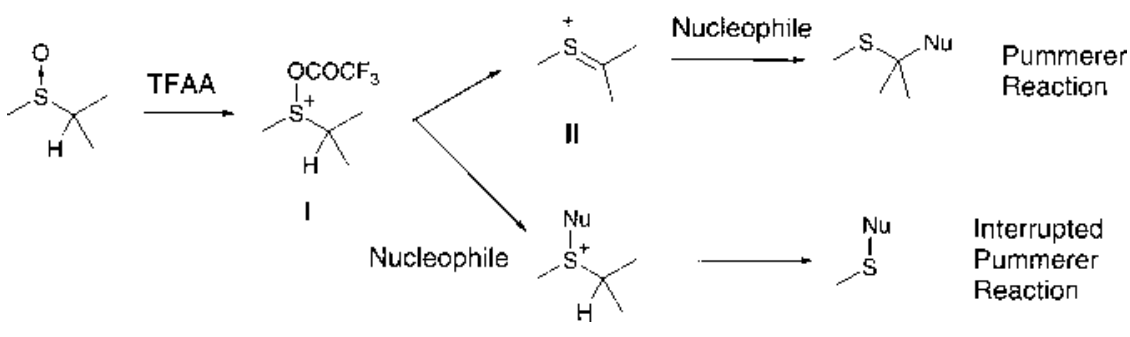

Chart 1 
tetraisopropoxide followed by sodium borohydride reduction of the resulting imine gave the secondary amine 3 . This amine was condensed with 2-phenylsulfanylacetyl chloride to afford the amide $\mathbf{4}$. Treatment of $\mathbf{4}$ with aluminum hydride selectively reduced the amide carbonyl to give the tertiary amine 5 in good yield. Oxidation of 5 and $\mathbf{4}$ with sodium metaperiodate in aqueous acetone afforded $\mathbf{6}$ and 7, respectively.

Treatment of the alkyl sulfoxide $\mathbf{6}$ with trifluoroacetic anhydride (TFAA) in tetrahydrofuran (THF) at room temperature (r.t.) gave two products, 8 and $\mathbf{9}$, in yields of $54 \%$ and $40 \%$, respectively. The products were readily separated in a pure form by column chromatography over silica gel. They showed the same molecular peak at $\mathrm{m} / \mathrm{z} 505$ in their respec-

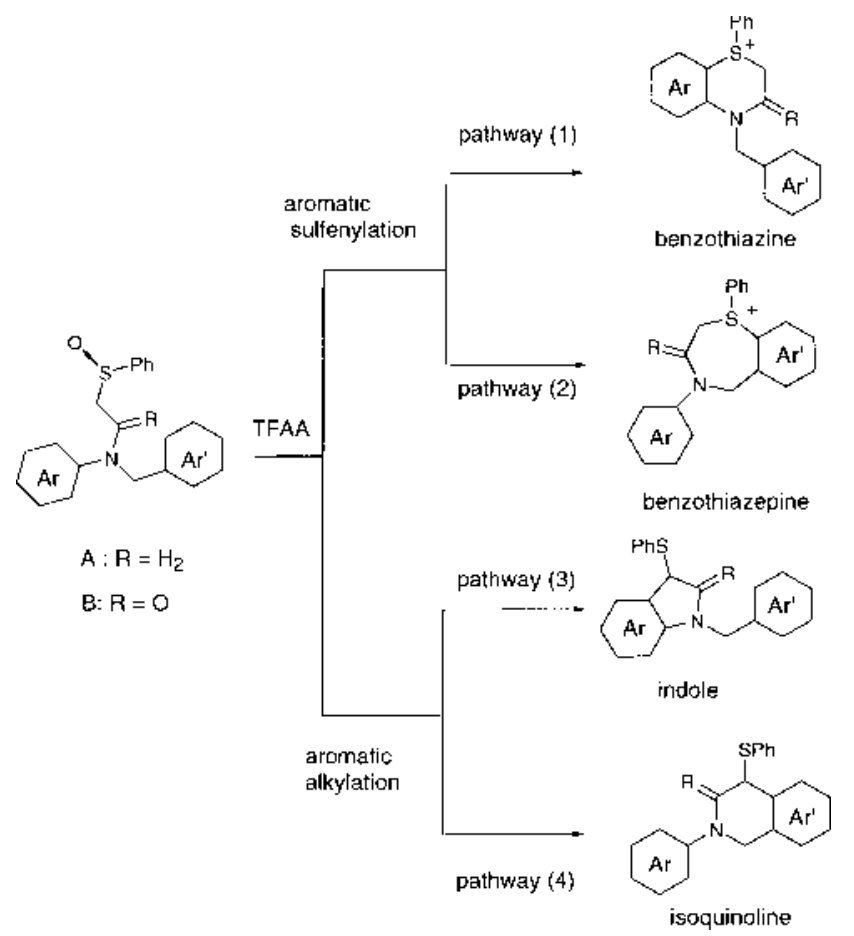

Chart 2 tive mass spectrum, which corresponds to the formula $\mathrm{C}_{25} \mathrm{H}_{22} \mathrm{~F}_{3} \mathrm{NO}_{5} \mathrm{~S}$, containing the trifluoroacetate moiety. This showed that both 8 and $\mathbf{9}$ are aromatic sulfenylation products. Furthermore, the behaviors in the mass spectra and the chromatography strongly suggested that they are sulfurane derivatives with an $\mathrm{O}-\mathrm{S}$ covalent bond, not a sulfonium salt. ${ }^{10,11)}$ The structures of these products were established by spectroscopic means. The assignments of NMR spectra (Fig. 1) indicated that $\mathbf{8}$ and $\mathbf{9}$ are regioisomeric compounds possessing a 1,4-benzothiazine ring system formed by the sulfenylation path (1) shown in Chart 2.

The correctness of this assignment to these products was confirmed chemically. The treatment of $\mathbf{8}$ with sodium methoxide in methanol at r.t. produced an aniline derivative 10 carrying $\mathrm{SPh}$ group in a quantitative yield. Similar treatment of 9 with sodium methoxide gave another aniline derivative, 11. The NMR spectra clearly indicated that they are regioisomeric to each other. The formation of the aniline derivatives can be rationalized in terms of the fission of the thiazine ring by a base catalyzed $E 2$ elimination reaction, followed by hydrolysis of the immonium salt $\mathbf{1 3}$ derived from the enamine 12, as shown in Chart 4 . The results confirmed that the Pummerer reaction of $\mathbf{6}$ induces a sulfenylation path (1) in an exclusive manner.

On the other hand, the $\alpha$-acyl sulfoxide 7, when similarly treated with TFAA as described above, gave $\mathbf{1 4}$ in $99 \%$ yield. The structure of this product was established by spectroscopic means. The assignment of the aromatic protons of the ${ }^{1} \mathrm{H}-\mathrm{NMR}$ spectra using heteronuclear multiple bond correlation (HMBC), as shown in Fig. 2, indicated that the product has a 2-oxo-indole skeleton rather than the 3-oxo-isoquinoline one.

This assigned structure was also confirmed by chemical transformations to several indole derivatives. Reaction of $\mathbf{1 4}$ with $\mathrm{NiCl}_{2}-\mathrm{NaBH}_{4}$ caused the reductive desulfurization of the $\mathrm{PhS}$ group, to give the 2-oxo-2,3-dihydroindole 15 in $86 \%$ yield. Reduction of $\mathbf{1 4}$ with aluminum hydride gave the indole 16 as a major product (86\%), and 2,3-dihydroindole 17 as a minor one (14\%). Oxidation of 14 with $\mathrm{NaIO}_{4}$ caused concomitant desulfurylation to give the isatin derivative $\mathbf{1 8}$
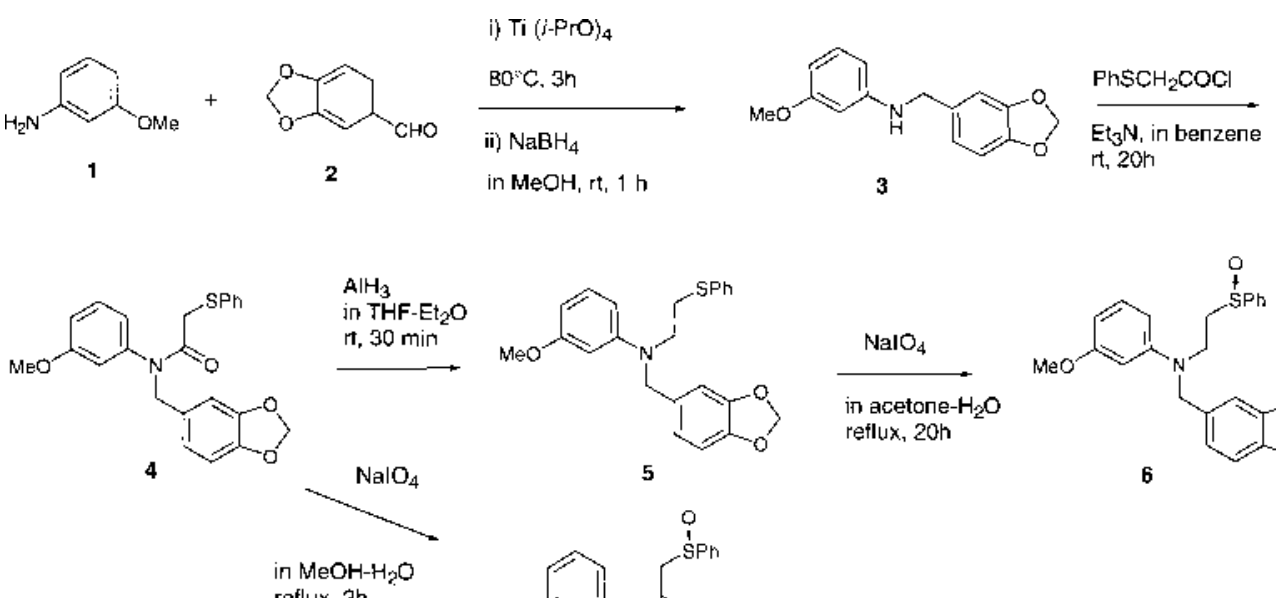

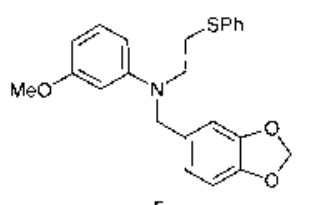

5<smiles>Cc1cccc(N(Cc2ccc3c(c2)OCO3)C(=O)COC(C)O)c1</smiles>

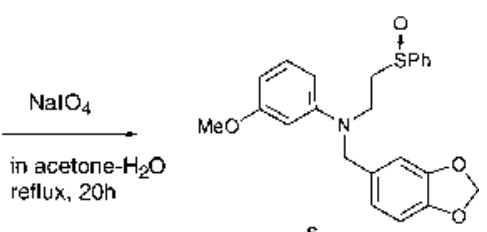

b

Chart 3 
Assiginment of ${ }^{1} H-N M M R$ of 6
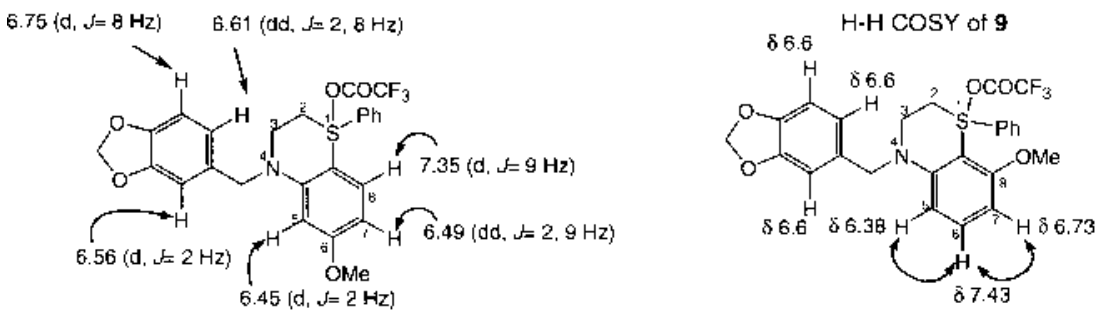

NOESY of 9

Fig. 1
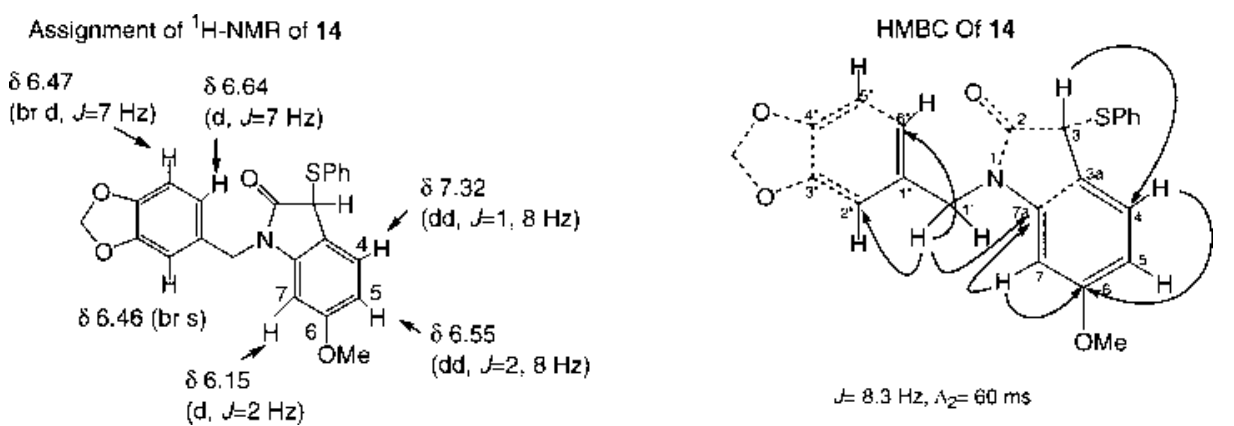

Fig. 2
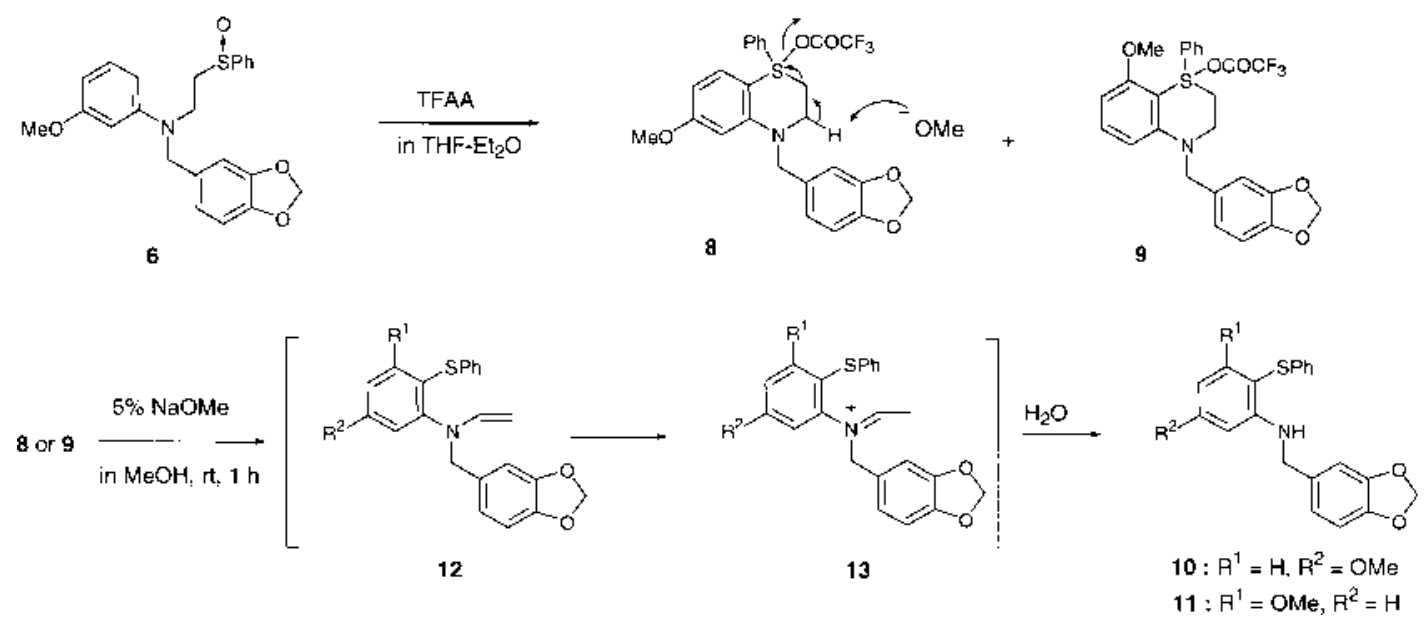

Chart 4<smiles>COc1cccc(N(Cc2ccc3c(c2)OCO3)C(=O)C[SnH](O)c2ccccc2)c1</smiles>

7

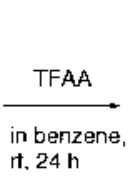

$99 \%$<smiles>COc1ccc2cccn2c1Cc1ccc2c(c1)OCO2</smiles>

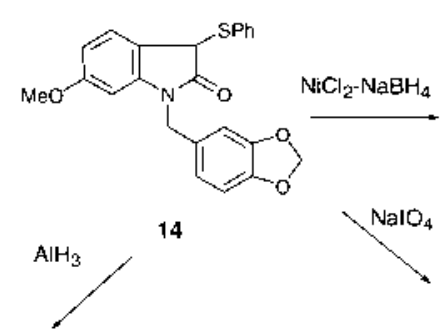<smiles>[O-]Oc1ccc2c(c1)N(Cc1ccc3c(c1)OCO3)CC2</smiles>

17<smiles>COc1ccc2c(c1)N(Cc1ccc3c(c1)OCO3)C(=O)C2</smiles>

15<smiles>COc1cccc(N(Cc2ccc3c(c2)OCO3)C(C)=O)c1</smiles>

Chart 5 


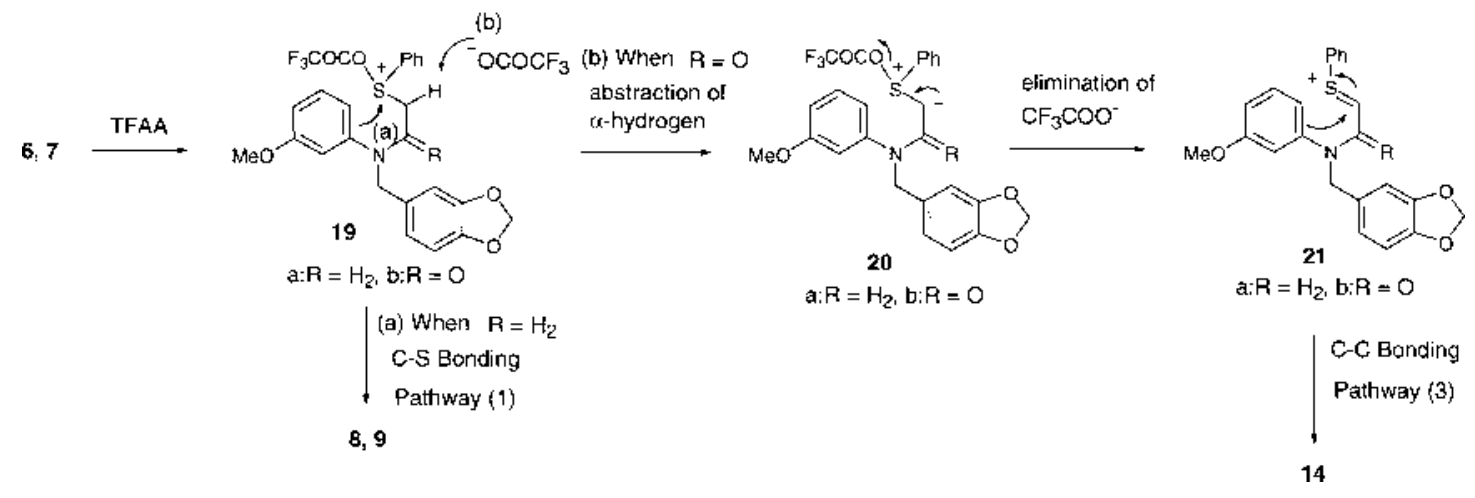

Chart 6

(42\%). Thus, the Pummerer reaction of 7 induced an alkylation path (3) in an exclusive manner.

The formation mechanism of the products is proposed as shown in Chart 6. The process begins in a normal Pummerer reaction with activation of the sulfoxide oxygen. Attack by the neighboring electron-rich aromatic ring on the sulfur of the acylated sulfoxide species, 19a, forms a benzothiazine nucleus as the sulfurane trifluoroacetates $\mathbf{8}$ and $\mathbf{9}$. On the other hand, the formation of 2-oxo-dihydroindole 14 can be rationalized by the generally accepted mechanism of the Pummerer reaction. This process involves a nucleophilic attack of the aromatic ring on the cationic carbon of the sulfonium ion $\mathbf{2 1 b}$, which is formed via the sulfur ylide species $20 \mathrm{~b}$ that is produced by the abstraction of the sulfinyl $\alpha$-hydrogen.

The results demonstrated that the reaction path depends on the difference in acidity of the proton attached to the sulfinyl $\alpha$-carbon. In the simple alkyl sulfoxide 6 , the process of the conversion of 19a to the corresponding ylide 20a may be retarded, since the $\alpha$-proton, because of the absence of an electron-withdrawing group, is not acidic enough to be abstracted by a weak basic anion species such as trifluoroacetate. This prohibits the aromatic alkylation path through the sulfonium ion 21a; instead, the substitution reaction on the sulfur atom of 19a proceeds if the aromatic ring is highly nucleophilic.

The $\alpha$-proton of the $\alpha$-acyl sulfoxide 7 is apparently more acidic than that of the simple alkyl sulfoxide 6 . This facilitates the formation of the sulfonium ion $\mathbf{2 1 b}$ through the ylide 20b that is formed by the abstraction of the $\alpha$-proton by an anion species, thus inducing the aromatic alkylation in an exclusive manner.

The results also demonstrated that the reaction path greatly depended on the ring size formed by each cyclization; in the aromatic alkylation reaction, the process of 5-exo-trig was favored over that of 6-exo-trig, and in the aromatic sulfenylation reaction the process of 6-exo-tet was favored over that of 7-exo-tet. This observed preference coincided well with the Baldwin rule. $^{12)}$

In summary, the interrupted Pummerer reaction of the simple alkyl sulfoxide $\mathbf{6}$ provided a method for constructing the benzothiazine ring system. On the other hand, the Pummerer reaction of the $\alpha$-acyl sulfoxide 7 , as already reported by Y. Tamura et al. in the reactions of similar $\alpha$-acyl sulfoxides, ${ }^{13)}$ provided a method for preparing the 2 -oxoindole ring system.

\section{Experimental}

General Procedures Melting points were taken on a Yanagimoto SPM1 hot-stage melting point apparatus. Thin layer chromatography (TLC) was performed on Merck precoated Silica gel $60 \mathrm{~F}_{254}$ plates (Merck). Column chromatography was carried out with silica gel (Wakogel C-200). Medium pressure liquid chromatography (MPLC) was performed on a $\mathrm{Ku}-$ sano CIG prepacked column. IR spectra were obtained as $\mathrm{KBr}$ disks with a HORIBA FT-710 spectrometer and are given in $\mathrm{cm}^{-1}$. NMR spectra were measured on a JEOL JNM-EX90 $\left({ }^{1} \mathrm{H}-\mathrm{NMR} 90 \mathrm{MHz},{ }^{13} \mathrm{C}-\mathrm{NMR} 22.5 \mathrm{MHz}\right)$ or JEOL JNM-AL $300\left({ }^{1} \mathrm{H}-\mathrm{NMR} 300 \mathrm{MHz},{ }^{13} \mathrm{C}-\mathrm{NMR} 75.0 \mathrm{MHz}\right)$ spectrometer in $\mathrm{CDCl}_{3}$ with tetramethylsilane as an internal standard, and the chemical shifts are given in $\delta$ values. Low-resolution MS spectra (LR-MS) and high-resolution MS spectra (HR-MS) were determined on a JEOL JMSHX110 A or JMS-D300 spectrometer at $70 \mathrm{eV}$ with a direct inlet system. The organic extract from each reaction mixture was washed with brine, dried over anhydrous $\mathrm{Na}_{2} \mathrm{SO}_{4}$ or $\mathrm{MgSO}_{4}$ before concentration in vacuo.

$\mathrm{N}$-(3,4-Methylenedioxyphenyl)methyl-3-methoxyaminobenzene (3) A mixture of $1(10.0 \mathrm{~g}, 66.7 \mathrm{mmol}), 2(10.0 \mathrm{~g}, 81.3 \mathrm{mmol})$ and titanium tetraisopropoxide $(28.0 \mathrm{~g}, 98.6 \mathrm{mmol})$ was heated at $80^{\circ} \mathrm{C}$ for $3 \mathrm{~h}$. After cooling, the reaction mixture was diluted with $\mathrm{MeOH}(100 \mathrm{ml})$. To this solution, $\mathrm{NaBH}_{4}(2.5 \mathrm{~g}, 65.8 \mathrm{mmol})$ was added in small portions under ice-cooling. The reaction mixture was stirred at r.t. for $1 \mathrm{~h}$ and concentrated in vacuo. Water $(c a .40 \mathrm{ml})$ was added to the residue, and the mixture was diluted with $\mathrm{MeOH}(\mathrm{ca} .500 \mathrm{ml})$. After removal of precipitated inorganic materials by filtration, the filtrate was concentrated in vacuo. The residue was dissolved in water and extracted with $\mathrm{CHCl}_{3}$. Column chromatography of the product with hexane/ethyl acetate $(9: 1)$ gave $3(1.7 \mathrm{~g}, 99 \%)$ as colorless needles, mp $49-51{ }^{\circ} \mathrm{C}$, crystallized from $\mathrm{Et}_{2} \mathrm{O}$-hexane. IR: 3422,1618 , 1589, 1520. ${ }^{1} \mathrm{H}-\mathrm{NMR}(90 \mathrm{MHz}): 3.74(3 \mathrm{H}, \mathrm{s}, \mathrm{MeO}), 4.00(1 \mathrm{H}, \mathrm{brs}, \mathrm{NH})$, $4.20\left(2 \mathrm{H}, \mathrm{s}, \mathrm{ArCH}_{2} \mathrm{~N}-\right), 5.92\left(2 \mathrm{H}, \mathrm{s}, \mathrm{OCH}_{2} \mathrm{O}\right), 6.1-7.2(7 \mathrm{H}, \mathrm{m}, \mathrm{ArH}) .{ }^{13} \mathrm{C}-$ NMR (22.5 MHz): 48.0 (t), 54.9 (q), $98.8(\mathrm{~d}), 108.8(\mathrm{t}), 102.6(\mathrm{~d}), 105.9(\mathrm{~d})$, 107.9 (d), 108.1 (d), 120.4 (d), 129.8 (d), 133.2 (s), 146.6 (s), 147.8 (s), 149.4 (s), 160.7 (s). LR-MS m/z: $257\left(\mathrm{M}^{+}\right.$), 135 (base peak). Anal. Calcd for $\mathrm{C}_{15} \mathrm{H}_{15} \mathrm{NO}_{3}: \mathrm{C}, 70.02 ; \mathrm{H}, 5.88 ; \mathrm{N}, 5.44$. Found: C, 70.02; H, 5.94; N, 5.34 .

$\boldsymbol{N}$-(3-Methoxyphenyl)- $\boldsymbol{N}$-(3,4-methylenedioxyphenyl)methyl-2-phenylsulfanylacetamide (4) A solution of 2-phenylsulfanylacetic acid $(14.7 \mathrm{~g}$, $87.5 \mathrm{mmol})$ in oxalyl chloride $(37.0 \mathrm{ml}, 437 \mathrm{mmol})$ was stirred at r.t. for $1 \mathrm{~h}$. Removal of excess oxalyl chloride by repeated evaporation under reduced pressure gave an oily material. To a solution of this chloride in benzene $(200 \mathrm{ml})$ a solution of the amine $3(15.0 \mathrm{~g}, 58.4 \mathrm{mmol})$ and $\mathrm{Et}_{3} \mathrm{~N}(8.8 \mathrm{~g}$, $87.1 \mathrm{mmol})$ in benzene $(200 \mathrm{ml})$ was slowly added under ice-cooling, and the mixture was stirred at r.t. for $20 \mathrm{~h}$. After removal of precipitated materials by filtration, the filtrate was concentrated in vacuo. The residue was extracted with $\mathrm{CHCl}_{3}$ then washed with $5 \% \mathrm{HCl}, 5 \% \mathrm{NaOH}$, and brine. The residual oil was chromatographed and eluted with ethyl acetate/hexane $(1: 4)$ to give $4(22.6 \mathrm{~g}, 95 \%)$ as colorless prisms, $\mathrm{mp} 85-87^{\circ} \mathrm{C}$, crystallized from ethyl acetate-hexane. IR: 1633, 1603, 1489. ${ }^{1} \mathrm{H}-\mathrm{NMR}(90 \mathrm{MHz}): 3.52(2 \mathrm{H}, \mathrm{s}$, $\left.-\mathrm{CH}_{2} \mathrm{~S}-\right), 3.72(3 \mathrm{H}, \mathrm{s}, \mathrm{MeO}), 4.76\left(2 \mathrm{H}, \mathrm{s}, \mathrm{ArCH}_{2} \mathrm{~N}-\right), 5.92\left(2 \mathrm{H}, \mathrm{s}, \mathrm{OCH}_{2} \mathrm{O}\right)$, 6.4-7.4 (12H, m, ArH, PhH). ${ }^{13} \mathrm{C}-\mathrm{NMR}(22.5 \mathrm{MHz}): 37.4(\mathrm{t}), 53.1(\mathrm{t}), 55.3$ (q), 100.9 (t), 107.9 (d), 109.4 (d), 113.9 (d), 114.1 (d), 120.5 (d), 122.3 (d), 126.7 (d), $128.8(\mathrm{~d} \times 2), 130.2(\mathrm{~d}), 130.3(\mathrm{~d} \times 2), 130.9(\mathrm{~s}), 135.5(\mathrm{~s}), 142.6$ (s), 146.9 (s), 147.6 (s), 160.3 (s), 168.3 (s). LR-MS m/z: $407\left(\mathrm{M}^{+}\right), 135$ (base peak). Anal. Calcd for $\mathrm{C}_{23} \mathrm{H}_{21} \mathrm{NO}_{4} \mathrm{~S}: \mathrm{C}, 67.79 ; \mathrm{H}, 5.19 ; \mathrm{N}, 3.44$. Found: C, 67.79; H, 5.29; N, 3.28.

$N$-(3,4-Methylenedioxyphenylmethyl)- $N$-(2-phenylsulfanylethyl)-3- 
methoxyaminobenzene (5) A solution of $4(2.0 \mathrm{~g}, 4.91 \mathrm{mmol})$ in dry $\mathrm{Et}_{2} \mathrm{O}-\mathrm{THF}(1: 1)(20 \mathrm{ml})$ was added to a solution of $\mathrm{AlH}_{3}$ in dry $\mathrm{Et}_{2} \mathrm{O}$ $(20 \mathrm{ml})$, prepared in situ from $\mathrm{LiAlH}_{4}(500 \mathrm{mg})$ and $\mathrm{AlCl}_{3}(430 \mathrm{mg})$ under an argon atmosphere. The mixture was stirred at r.t. for $30 \mathrm{~min}$. The reaction mixture was diluted with $\mathrm{CHCl}_{3}$ and passed through a short column of $\mathrm{SiO}_{2}$. The eluate was concentrated in vacuo. The residual oil was chromatographed and eluted with benzene to give $5(1.6 \mathrm{~g}, 84 \%)$ as a pale yellow oil. IR: 1610, 1500. UV: 254 (20600), 288 (8800). ${ }^{1} \mathrm{H}-\mathrm{NMR}(300 \mathrm{MHz})$ : $3.0-3.2\left(2 \mathrm{H}, \mathrm{m},-\mathrm{NCH}_{2} \mathrm{CH}_{2} \mathrm{~S}-\right), 3.5-3.7\left(2 \mathrm{H}, \mathrm{m},-\mathrm{NCH}_{2} \mathrm{CH}_{2} \mathrm{~S}-\right), 3.71$ $(3 \mathrm{H}, \mathrm{s}, \mathrm{MeO}), 4.42\left(2 \mathrm{H}, \mathrm{s}, \mathrm{ArCH}_{2} \mathrm{~N}-\right), 5.92\left(2 \mathrm{H}, \mathrm{s}, \mathrm{OCH}_{2} \mathrm{O}\right), 6.1-7.4(12 \mathrm{H}$, $\mathrm{m}, \mathrm{ArH}, \mathrm{PhH}) \cdot{ }^{13} \mathrm{C}-\mathrm{NMR}(75.0 \mathrm{MHz}): 30.7(\mathrm{t}), 50.7(\mathrm{t}), 54.5(\mathrm{t}), 55.1(\mathrm{q})$, 99.0 (d), 100.9 (t), 101.7 (d), 105.4 (d), 107.2 (d), 108.3 (d), 119.7 (d), 126.5 (d), $129.0(\mathrm{~d} \times 2), 129.9(\mathrm{~d} \times 2), 130.0(\mathrm{~d}), 132.5(\mathrm{~s}), 135.4(\mathrm{~s}), 146.5(\mathrm{~s})$, 148.0 (s), 149.1 (s), 160.8 (s). LR-MS m/z: $393\left(\mathrm{M}^{+}\right), 135$ (base peak). HRMS $m / z\left(\mathrm{M}^{+}\right)$: Calcd for $\mathrm{C}_{23} \mathrm{H}_{23} \mathrm{NO}_{3} \mathrm{~S}: 393.1399$. Found: 393.1416 .

$N$-(3,4-Methylenedioxyphenyl)methyl- $N$-(2-phenylsulfinylethyl)-3methoxyaminobenzene (6) To a solution of $5(1.0 \mathrm{~g}, 2.54 \mathrm{mmol})$ in acetone $(150 \mathrm{ml})$, a solution of $\mathrm{NaIO}_{4}(820 \mathrm{mg}, 3.83 \mathrm{mmol})$ in $\mathrm{H}_{2} \mathrm{O}(15 \mathrm{ml})$ was added, and the mixture was heated under reflux for $20 \mathrm{~h}$. After removal of the inorganic precipitate, the filtrate was concentrated in vacuo and extracted with $\mathrm{CHCl}_{3}$. The residual oil was chromatographed and eluted with ethyl acetate/hexane $(1: 3)$ to give $6(848 \mathrm{mg}, 82 \%)$ as a brownish yellow gum. IR: 1610, 1500. ${ }^{1} \mathrm{H}-\mathrm{NMR}(300 \mathrm{MHz}): 2.8-3.2\left(2 \mathrm{H}, \mathrm{m},-\mathrm{NCH}_{2} \mathrm{CH}_{2} \mathrm{~S}-\right), 3.6-$ $4.0\left(2 \mathrm{H}, \mathrm{m},-\mathrm{NCH}_{2} \mathrm{CH}_{2} \mathrm{~S}-\right), 3.73(3 \mathrm{H}, \mathrm{s}, \mathrm{MeO}), 4.40(1 \mathrm{H}, \mathrm{d}, J=17 \mathrm{~Hz}$, $\left.\mathrm{ArCH}_{2} \mathrm{~N}-\right), 4.47\left(1 \mathrm{H}, \mathrm{d}, J=17 \mathrm{~Hz}, \mathrm{ArCH}_{2} \mathrm{~N}-\right), 5.92\left(2 \mathrm{H}, \mathrm{s}, \mathrm{OCH}_{2} \mathrm{O}\right), 6.2-$ $7.1(7 \mathrm{H}, \mathrm{m}, \mathrm{ArH}), 7.4-7.6(5 \mathrm{H}, \mathrm{m}, \mathrm{PhH}) .{ }^{13} \mathrm{C}-\mathrm{NMR}(75.0 \mathrm{MHz}): 43.9(\mathrm{t})$, $53.8(\mathrm{t}), 54.7(\mathrm{t}), 55.1(\mathrm{q}), 99.5(\mathrm{~d}), 100.9(\mathrm{t}), 102.2(\mathrm{~d}), 105.8(\mathrm{~d}), 107.1(\mathrm{~d})$, 108.3 (d), 119.7 (d), $123.8(\mathrm{~d} \times 2), 129.3(\mathrm{~d} \times 2), 130.1(\mathrm{~d}), 131.0(\mathrm{~d}), 132.1$ (s), 143.3 (s), 146.6 (s), 147.9 (s), 148.8 (s), 160.9 (s). LR-MS m/z: 409 $\left(\mathrm{M}^{+}\right), 135$ (base peak).

$N$-(3-Methoxyphenyl)- $N$-(3,4-methylenedioxyphenyl)methyl-2-phenylsulfinylacetamide (7) A solution of $4(10 \mathrm{~g}, 24.6 \mathrm{mmol})$ and $\mathrm{NaIO}_{4}(7.9 \mathrm{~g}$, $36.9 \mathrm{mmol})$ in $\mathrm{MeOH}(150 \mathrm{ml})$ and $\mathrm{H}_{2} \mathrm{O}(50 \mathrm{ml})$ was heated under reflux for $2 \mathrm{~h}$. After removal of inorganic precipitates by filtration, the filtrate was concentrated in vacuo. The residue was extracted with $\mathrm{CHCl}_{3}$ and washed with brine. The product was chromatographed and eluted with ethyl acetate/ hexane $(2: 3)$ to give $7(10 \mathrm{~g}, 99 \%)$ as a brownish yellow gum. IR: 1651 , 1603, 1491, 1040. UV: 281 (6800). ${ }^{1} \mathrm{H}-\mathrm{NMR}(90 \mathrm{MHz}): 3.48$ (1H, d, $J=14$ $\left.\mathrm{Hz},-\mathrm{CH}_{2} \mathrm{~S}-\right), 3.87\left(1 \mathrm{H}, \mathrm{d}, J=14 \mathrm{~Hz},-\mathrm{CH}_{2} \mathrm{~S}-\right), 3.78(3 \mathrm{H}, \mathrm{s}, \mathrm{MeO}), 4.58$ $\left(\mathrm{H}, \mathrm{d}, J=14 \mathrm{~Hz}, \operatorname{ArCH}_{2} \mathrm{~N}-\right), 4.80\left(\mathrm{H}, \mathrm{d}, J=14 \mathrm{~Hz}, \operatorname{ArCH}_{2} \mathrm{~N}-\right), 5.93(2 \mathrm{H}$, $\left.\mathrm{s}, \mathrm{OCH}_{2} \mathrm{O}\right), 6.2-7.7(12 \mathrm{H}, \mathrm{m}, \mathrm{ArH}, \mathrm{PhH})$. LR-MS m/z: $423\left(\mathrm{M}^{+}\right), 135$ (base peak). HR-MS $m / z\left(M^{+}\right)$: Calcd for $\mathrm{C}_{23} \mathrm{H}_{21} \mathrm{NO}_{5} \mathrm{~S}$ : 423.1140 . Found: 423.1155 .

Pummerer Reaction of 6 TFAA $(0.17 \mathrm{ml}, 1.21 \mathrm{mmol})$ was added to a solution of $\mathbf{6}(100 \mathrm{mg}, 0.24 \mathrm{mmol})$ in THF $(10 \mathrm{ml})$ at r.t. under an argon atmosphere, and the mixture was stirred for $1 \mathrm{~h}$. The reaction mixture was concentrated in vacuo. The residual oil was chromatographed and eluted with $\mathrm{CHCl}_{3} / \mathrm{MeOH}(5: 1)$ to give $\mathbf{8}(66 \mathrm{mg}, 54 \%)$ as a colorless gum and $\mathbf{9}$ ( $49 \mathrm{mg}, 40 \%$ ) as colorless prisms, crystallized from ethyl acetate/hexane, mp $135-137^{\circ} \mathrm{C}$.

1-Trifluoroacetoxy-6-methoxy-4-(3,4-methylenedioxyphenyl)methyl-1phenyl-1,2,3,4-tetrahydro-1,4-benzothiazine (8): IR: 1685, 1604, 1504. UV: 233 (31900), 286 (6400), 317 (4100). ${ }^{1} \mathrm{H}-\mathrm{NMR}$ (300 MHz): 3.1-3.9 (4H, $\mathrm{m}, \mathrm{C} 2-\mathrm{H}, \mathrm{C} 3-\mathrm{H}), 3.80(3 \mathrm{H}, \mathrm{s}, \mathrm{MeO}), 4.48\left(1 \mathrm{H}, \mathrm{d}, J=16 \mathrm{~Hz}, \mathrm{ArCH}_{2} \mathrm{~N}-\right), 4.54$ $\left(1 \mathrm{H}, \mathrm{d}, J=16 \mathrm{~Hz}, \mathrm{ArCH}_{2} \mathrm{~N}-\right), 5.95\left(1 \mathrm{H}, \mathrm{d}, J=2 \mathrm{~Hz}, \mathrm{OCH}_{2} \mathrm{O}\right), 5.95(1 \mathrm{H}, \mathrm{d}$, $\left.J=2 \mathrm{~Hz}, \mathrm{OCH}_{2} \mathrm{O}\right), 6.45(1 \mathrm{H}, \mathrm{d}, J=2 \mathrm{~Hz}, \mathrm{C} 5-\mathrm{H}), 6.49(1 \mathrm{H}, \mathrm{dd}, J=2,9 \mathrm{~Hz}$, C7-H), $6.56\left(1 \mathrm{H}, \mathrm{d}, J=2 \mathrm{~Hz}, \mathrm{C} 2^{\prime \prime}-\mathrm{H}\right), 6.61\left(1 \mathrm{H}, \mathrm{dd}, J=2,8 \mathrm{~Hz}, \mathrm{C} 6{ }^{\prime \prime}-\mathrm{H}\right), 6.75$ $\left(1 \mathrm{H}, \mathrm{d}, J=8 \mathrm{~Hz}, \mathrm{C} 5^{\prime \prime}-\mathrm{H}\right), 7.35(1 \mathrm{H}, \mathrm{d}, J=9 \mathrm{~Hz}, \mathrm{C} 8-\mathrm{H}), 7.5-7.7(5 \mathrm{H}, \mathrm{m}$, PhH). ${ }^{13} \mathrm{C}-N M R(75.0 \mathrm{MHz}): 36.5(\mathrm{t}), 41.3(\mathrm{t}), 55.6(\mathrm{q}), 55.8(\mathrm{t}), 86.4(\mathrm{~s})$, 99.7 (d), 101.3 (t), 106.0 (d), 106.7 (d), 108.7 (d), 119.8 (d), 127.8 (s), 128.8 $(\mathrm{d} \times 2), 129.0(\mathrm{~s}), 130.9(\mathrm{~d} \times 2), 133.0(\mathrm{~d}), 136.0(\mathrm{~d}), 147.2(\mathrm{~s}), 147.4(\mathrm{~s})$, 148.4 (s), 166.2 (s). LR-MS m/z: $505\left(\mathrm{M}^{+}\right), 135$ (base peak). HR-MS $\mathrm{m} / \mathrm{z}$ $\left(\mathrm{M}^{+}\right)$: Calcd for $\mathrm{C}_{25} \mathrm{H}_{22} \mathrm{~F}_{3} \mathrm{NO}_{5} \mathrm{~S}$ : 505.1171 Found: 505.1160.

1-Trifluoroacetoxy-8-methoxy-4-(3,4-methylenedioxyphenyl)methyl-1phenyl-1,2,3,4-tetrahydro-1,4-benzothiazine (9): IR: 1683, 1506. UV: 287 (3300), 332 (4500). ${ }^{1} \mathrm{H}-\mathrm{NMR}\left(300 \mathrm{MHz}, \mathrm{CD}_{3} \mathrm{OD}\right): 3.4-4.9$ (4H, m, C2-H, C3-H), $3.81(3 \mathrm{H}, \mathrm{s}, \mathrm{MeO}), 4.52\left(1 \mathrm{H}, \mathrm{d}, J=17 \mathrm{~Hz}, \mathrm{ArCH}_{2} \mathrm{~N}-\right), 4.62(1 \mathrm{H}, \mathrm{d}$, $\left.J=17 \mathrm{~Hz}, \mathrm{ArCH}_{2} \mathrm{~N}-\right), 5.93\left(2 \mathrm{H}, \mathrm{s}, \mathrm{OCH}_{2} \mathrm{O}\right), 6.38(1 \mathrm{H}, \mathrm{d}, J=8 \mathrm{~Hz}, \mathrm{C} 7-\mathrm{H})$, $6.60-6.63(3 \mathrm{H}, \mathrm{m}, \mathrm{ArH}), 6.73(1 \mathrm{H}, \mathrm{d}, J=8 \mathrm{~Hz}, \mathrm{C} 5-\mathrm{H}), 7.43(1 \mathrm{H}, \mathrm{t}, J=8 \mathrm{~Hz}$, C6-H), 7.5-7.8 (5H, m, PhH). ${ }^{13} \mathrm{C}-\mathrm{NMR}\left(75.0 \mathrm{MHz}, \mathrm{CD}_{3} \mathrm{OD}\right): 35.8(\mathrm{t})$, $41.0(\mathrm{t}), 56.2(\mathrm{t}), 56.9(\mathrm{q}), 85.1(\mathrm{~s}), 99.4(\mathrm{~d}), 101.2(\mathrm{t}), 106.8(\mathrm{~d}), 107.6(\mathrm{~d})$, $108.6(\mathrm{~d}), 119.8(\mathrm{~d}), 127.8(\mathrm{~s}), 128.8(\mathrm{~d} \times 2), 129.5(\mathrm{~s}), 130.7(\mathrm{~d} \times 2), 132.9$ (d), 136.2 (d), $147.2(\mathrm{~s} \times 2), 148.3$ (s), 159.7 (s). LR-MS m/z: $505\left(\mathrm{M}^{+}\right), 135$ (base peak). HR-MS $m / z\left(\mathrm{M}^{+}\right)$: Calcd for $\mathrm{C}_{25} \mathrm{H}_{22} \mathrm{~F}_{3} \mathrm{NO}_{5} \mathrm{~S}$ : 505.1171 . Found:

\subsection{5.}

Reaction of 8 with NaOMe A solution of $8(50 \mathrm{mg}, 0.10 \mathrm{mmol})$ in $5 \%$ $\mathrm{NaOMe}-\mathrm{MeOH}(10 \mathrm{ml})$ was stirred at r.t. for $1 \mathrm{~h}$. The reaction mixture was concentrated in vacuo and extracted with $\mathrm{CHCl}_{3}$. The residue was chromatographed and eluted with ethyl acetate/hexane $(1: 2)$ to give $N-(3,4-$ methylenedioxyphenyl)methyl-5-methoxy-2-(phenylsulfanyl)aminobenzene (10) $(33 \mathrm{mg}, 92 \%)$ as a pale yellow oil. IR: $1600,1508,1488 .{ }^{1} \mathrm{H}-\mathrm{NMR}$ $(300 \mathrm{MHz}): 3.75(3 \mathrm{H}, \mathrm{s}, \mathrm{MeO}), 4.21\left(2 \mathrm{H}, \mathrm{d}, J=5 \mathrm{~Hz}, \mathrm{ArCH}_{2} \mathrm{~N}-\right), 5.34(1 \mathrm{H}$, t, $J=5 \mathrm{~Hz}, \mathrm{NH}), 5.90\left(2 \mathrm{H}, \mathrm{s}, \mathrm{OCH}_{2} \mathrm{O}\right), 6.16(1 \mathrm{H}, \mathrm{d}, J=3 \mathrm{~Hz}, \mathrm{C} 6-\mathrm{H}), 6.27$ $(1 \mathrm{H}, \mathrm{dd}, J=3,8 \mathrm{~Hz}, \mathrm{C} 4-\mathrm{H}), 7.0-7.3(5 \mathrm{H}, \mathrm{m}, \mathrm{PhH}), 7.42(1 \mathrm{H}, \mathrm{d}, J=8 \mathrm{~Hz}$, C3-H). ${ }^{13} \mathrm{C}-\mathrm{NMR}(75.0 \mathrm{MHz}): 47.5$ (t), 56.1 (q), 99.9 (d), 100.9 (t), 101.2 (s), 104.1 (d), 107.5 (d), 108.2 (d), 120.0 (d), 125.0 (d), 125.9 (d×2), 128.8 $(\mathrm{d} \times 2), 131.8(\mathrm{~d}), 133.0(\mathrm{~s}), 136.6(\mathrm{~s}), 146.6(\mathrm{~s}), 147.8(\mathrm{~s}), 150.7$ (s), 161.6 (s). LR-MS: $m / z 365\left(\mathrm{M}^{+}\right), 135$ (base peak). HR-MS $m / z\left(\mathrm{M}^{+}\right)$: Calcd for $\mathrm{C}_{21} \mathrm{H}_{19} \mathrm{NO}_{3} \mathrm{~S}: 365.1083$. Found: 365.1063 .

Reaction of 9 with NaOMe A solution of $9(50 \mathrm{mg}, 0.10 \mathrm{mmol})$ in $1 \%$ $\mathrm{NaOMe}-\mathrm{MeOH}(10 \mathrm{ml})$ was stirred at r.t. for $2 \mathrm{~h}$. The reaction mixture was concentrated in vacuo and extracted with $\mathrm{CHCl}_{3}$. The residue was chromatographed and eluted with ethyl acetate/hexane $(1: 2)$ to give $N$ - $(3,4-$ methylenedioxyphenyl)methyl-3-methoxy-2-(phenylsulfanyl)aminobenzene (11) $(34 \mathrm{mg}, 94 \%)$ as a pale yellow oil. IR: $1589,1502,1488 .{ }^{1} \mathrm{H}-\mathrm{NMR}$ $(300 \mathrm{MHz}): 3.81(3 \mathrm{H}, \mathrm{s}, \mathrm{MeO}), 4.25\left(2 \mathrm{H}, \mathrm{d}, J=6 \mathrm{~Hz}, \mathrm{ArCH}_{2} \mathrm{~N}-\right), 5.61(1 \mathrm{H}$, t, $J=6 \mathrm{~Hz}, \mathrm{NH}), 5.91\left(2 \mathrm{H}, \mathrm{s}, \mathrm{OCH}_{2} \mathrm{O}\right), 6.30(1 \mathrm{H}, \mathrm{dd}, J=1,8 \mathrm{~Hz}, \mathrm{C} 4-\mathrm{H}), 6.34$ $(1 \mathrm{H}, \mathrm{dd}, J=1,8 \mathrm{~Hz}, \mathrm{C} 6-\mathrm{H}), 6.6-6.7(3 \mathrm{H}, \mathrm{m}, \mathrm{ArH}), 7.0-7.3(6 \mathrm{H}, \mathrm{m}, \mathrm{C} 5-\mathrm{H}$, PhH). ${ }^{13} \mathrm{C}$-NMR (75.0 MHz): 47.3 (t), 55.1 (q), 97.2 (d), 100.9 (t), 102.3 (d), 105.5 (s), 107.5 (d), 108.2 (d), 120.1 (d), 125.1 (d), 125.8 (d×2), 128.9 (d×2), 132.7 (s), 137.7 (s), 138.9 (d), 146.6 (s), 147.9 (s), 150.3 (s), 162.6 (s). LR-MS: $\mathrm{m} / \mathrm{z} 365\left(\mathrm{M}^{+}\right), 149$ (base peak). HR-MS $\mathrm{m} / \mathrm{z}\left(\mathrm{M}^{+}\right)$: Calcd for $\mathrm{C}_{21} \mathrm{H}_{19} \mathrm{NO}_{3} \mathrm{~S}$ : 365.1085 . Found: 365.1085 .

Pummerer Reaction of 7 TFAA $(0.17 \mathrm{ml}, 1.21 \mathrm{mmol})$ was added to a solution of $7(100 \mathrm{mg}, 0.24 \mathrm{mmol})$ in benzene $(10 \mathrm{ml})$ at r.t. under an argon atmosphere, and the mixture was stirred for $1 \mathrm{~h}$. After removal of the solvent in vacuo, the residual oil was chromatographed and eluted with ethyl acetate/hexane (1:5) to give 6-methoxy-1-(3,4-methylenedioxyphenyl)methyl-2-oxo-3-phenylsulfanyl-2,3-dihydroindole (14) $(97 \mathrm{mg}, 99 \%)$ as colorless needles crystallized from $\mathrm{CHCl}_{3}-\mathrm{Et}_{2} \mathrm{O}, \mathrm{mp} 116-117^{\circ} \mathrm{C}$. IR: 1719,1626 , 1504. UV: 285 (7700). ${ }^{1} \mathrm{H}-\mathrm{NMR}(500 \mathrm{MHz}): 3.72(3 \mathrm{H}, \mathrm{s}, \mathrm{MeO}), 4.49(1 \mathrm{H}, \mathrm{d}$, $\left.J=16 \mathrm{~Hz}, \mathrm{ArCH}_{2} \mathrm{~N}-\right), 4.59\left(1 \mathrm{H}, \mathrm{d}, J=16 \mathrm{~Hz}, \mathrm{ArCH}_{2} \mathrm{~N}-\right), 4.59(1 \mathrm{H}, \mathrm{d}$, $J=1 \mathrm{~Hz}, \mathrm{C} 3-\mathrm{H}), 5.91\left(2 \mathrm{H}, \mathrm{s}, \mathrm{OCH}_{2} \mathrm{O}\right), 6.15(1 \mathrm{H}, \mathrm{d}, J=2 \mathrm{~Hz}, \mathrm{C} 7-\mathrm{H}), 6.46$ $\left(1 \mathrm{H}\right.$, br s, C2"-H), $6.47\left(1 \mathrm{H}\right.$, br d, $\left.J=7 \mathrm{~Hz}, \mathrm{C}^{\prime \prime}-\mathrm{H}\right), 6.55(1 \mathrm{H}, \mathrm{dd}, J=2,8 \mathrm{~Hz}$, C5-H), $6.64\left(1 \mathrm{H}, \mathrm{d}, J=7 \mathrm{~Hz}, \mathrm{C} 5^{\prime \prime}-\mathrm{H}\right), 7.1-7.4(5 \mathrm{H}, \mathrm{m}, \mathrm{PhH}), 7.32(1 \mathrm{H}, \mathrm{dd}$, $J=1,8 \mathrm{~Hz}, \mathrm{C} 4-\mathrm{H}) .{ }^{13} \mathrm{C}-\mathrm{NMR}(125 \mathrm{MHz}): 43.9$ (t), 48.9 (d), 55.4 (q), 97.3 (d), 101.1 (t), 106.5 (d), 107.7 (d), 108.3 (d), 117.9 (s), 120.5 (d), 126.0 (d), $128.8(\mathrm{~d} \times 3), 129.1(\mathrm{~s}), 130.8(\mathrm{~s}), 134.4(\mathrm{~d} \times 2), 144.3(\mathrm{~s}), 147.0(\mathrm{~s}), 148.0$ (s), 160.6 (s), 174.8 (s). LR-MS: $m / z 405\left(\mathrm{M}^{+}\right), 135$ (base peak). Anal. Calcd for $\mathrm{C}_{23} \mathrm{H}_{19} \mathrm{NO}_{4} \mathrm{~S}: \mathrm{C}, 68.13 ; \mathrm{H}, 4.72 ; \mathrm{N}, 3.45$. Found: C, 67.91; H, 4.81; N, 3.17.

6-Methoxy-1-(3,4-methylenedioxyphenyl)methyl-2-oxo-2,3-dihydroindole (15) To a stirred solution of $\mathbf{1 4}(300 \mathrm{mg}, 0.74 \mathrm{mmol})$ and $\mathrm{NiCl}_{2} \cdot 6 \mathrm{H}_{2} \mathrm{O}$ $(1.2 \mathrm{~g}, 5.04 \mathrm{mmol})$ in $\mathrm{MeOH}-\mathrm{THF}(3: 1)(15 \mathrm{ml})$ was added $\mathrm{NaBH}_{4}(600$ $\mathrm{mg}, 15.8 \mathrm{mmol}$ ) by portions at $0^{\circ} \mathrm{C}$, and stirring was continued at r.t. for $30 \mathrm{~min}$. The reaction mixture was filtered and the filtrate was concentrated in vacuo. The residue was extracted with $\mathrm{CHCl}_{3}$. The product was chromatographed and elued with ethyl acetate/hexane $(2: 3)$ to give (15) $(189 \mathrm{mg}, 86 \%)$ as colorless needles crystallized from $\mathrm{CHCl}_{3}-\mathrm{Et}_{2} \mathrm{O}, \mathrm{mp}$ 118- $120^{\circ} \mathrm{C}$. IR: $1709,1628,1504$. UV: 286 (7100). ${ }^{1} \mathrm{H}-\mathrm{NMR}(500 \mathrm{MHz})$ : $3.53(2 \mathrm{H}, \mathrm{s}, \mathrm{C} 3-\mathrm{H}), 3.75(3 \mathrm{H}, \mathrm{s}, \mathrm{MeO}), 4.78\left(2 \mathrm{H}, \mathrm{s}, \mathrm{ArCH}_{2} \mathrm{~N}-\right), 5.92(2 \mathrm{H}, \mathrm{s}$, $\left.\mathrm{OCH}_{2} \mathrm{O}\right), 6.34(1 \mathrm{H}, \mathrm{d}, J=2 \mathrm{~Hz}, \mathrm{C} 7-\mathrm{H}), 6.51(1 \mathrm{H}, \mathrm{dd}, J=2,8 \mathrm{~Hz}, \mathrm{C} 5-\mathrm{H}), 6.74$ $\left(1 \mathrm{H}, \mathrm{d}, J=8 \mathrm{~Hz}, \mathrm{C} 5^{\prime \prime}-\mathrm{H}\right), 6.79\left(1 \mathrm{H}, \mathrm{brs}, \mathrm{C} 2^{\prime \prime}-\mathrm{H}\right), 6.79(1 \mathrm{H}$, br d, $J=8 \mathrm{~Hz}$, C6"-H), $7.12(1 \mathrm{H}, \mathrm{d}, J=8 \mathrm{~Hz}, \mathrm{C} 4-\mathrm{H}) .{ }^{13} \mathrm{C}-\mathrm{NMR}(125 \mathrm{MHz}): 35.1$ (t), 43.6 $(\mathrm{t}), 55.5$ (q), 97.4 (d), $101.1(\mathrm{t}), 106.0$ (d), 107.9 (d), 108.3 (d), $116.3(\mathrm{~s})$, 120.8 (d), 124.8 (d), 129.7 (s), 145.4 (s), 147.1 (s), 148.1 (s), 159.8 (s), 175.9 (s). LR-MS: $m / z 297\left(\mathrm{M}^{+}\right), 135$ (base peak). Anal. Calcd for $\mathrm{C}_{17} \mathrm{H}_{15} \mathrm{NO}_{4}$ : C, 68.68; H, 5.09; N, 4.71. Found: C, 68.57; H, 5.20; N, 4.65.

Reduction of 14 with $\mathrm{AlH}_{3}$ A solution of $14(100 \mathrm{mg}, 0.25 \mathrm{mmol})$ in dry $\mathrm{Et}_{2} \mathrm{O}-\mathrm{THF}(1: 1)(10 \mathrm{ml})$ was added to a solution of $\mathrm{AlH}_{3}$ in dry $\mathrm{Et}_{2} \mathrm{O}$ $(10 \mathrm{ml})$ prepared in situ from $\mathrm{LiAlH}_{4}(86 \mathrm{mg})$ and $\mathrm{AlCl}_{3}(100 \mathrm{mg})$ under an argon atmosphere. The mixture was stirred at r.t. for $30 \mathrm{~min}$. The reaction mixture was diluted with $\mathrm{CHCl}_{3}$. The extract was washed with $5 \% \mathrm{NH}_{4} \mathrm{OH}$ and brine. The residual oil was chromatographed and eluted with ethyl acetate/hexane (1:4) to give $\mathbf{1 6}(59 \mathrm{mg}, 86 \%)$ as a colorless oil and $\mathbf{1 7}(10 \mathrm{mg}$, $14 \%)$ as a pale yellow oil.

6-Methoxy-1-(3,4-methylenedioxyphenyl)methylindole (16): IR: 1623, 1490. UV: 289 (9400). ${ }^{1} \mathrm{H}-\mathrm{NMR}$ (300 MHz): 3.81 (3H, s, MeO), 5.15 (2H, s, 
$\left.\mathrm{ArCH}_{2} \mathrm{~N}-\right), 5.91\left(2 \mathrm{H}, \mathrm{s}, \mathrm{OCH}_{2} \mathrm{O}\right), 6.46(1 \mathrm{H}, \mathrm{d}, J=3 \mathrm{~Hz}, \mathrm{C} 3-\mathrm{H}), 6.58(1 \mathrm{H}, \mathrm{d}$, $J=1 \mathrm{~Hz}, \mathrm{C} 2 "-\mathrm{H}), 6.63(1 \mathrm{H}$, br dd, $J=1,8 \mathrm{~Hz}, \mathrm{C} 6 "-\mathrm{H}), 6.73(1 \mathrm{H}, \mathrm{d}, J=8 \mathrm{~Hz}$, C5"-H), $6.74(1 \mathrm{H}$, br s, C7-H), $6.78(1 \mathrm{H}, \mathrm{dd}, J=2,9 \mathrm{~Hz}, \mathrm{C} 5-\mathrm{H}), 6.99(1 \mathrm{H}, \mathrm{d}$, $J=3 \mathrm{~Hz}, \mathrm{C} 2-\mathrm{H}), 7.50(1 \mathrm{H}, \mathrm{d}, J=9 \mathrm{~Hz}, \mathrm{C} 4-\mathrm{H}) .{ }^{13} \mathrm{C}-\mathrm{NMR}(75.0 \mathrm{MHz}): 49.9$ $(\mathrm{t}), 55.7(\mathrm{q}), 93.5(\mathrm{~d}), 101.1(\mathrm{t}), 101.6$ (d), 107.4 (d), 108.3 (d), 109.3 (d), 120.2 (d), 121.5 (d), 123.1 (s), 127.1 (d), 131.3 (s), 137.0 (s), 147.1 (s), 148.1 (s), 156.3 (s). LR-MS: $m / z 281\left(\mathrm{M}^{+}\right), 135$ (base peak). HR-MS $m / z$ $\left(\mathrm{M}^{+}\right)$: Calcd for $\mathrm{C}_{17} \mathrm{H}_{15} \mathrm{NO}_{3}: 281.1051$. Found: 281.1056 .

6-Methoxy-1-(3,4-methylenedioxyphenyl)methyl-2,3-dihydroindole (17): IR: 1620, 1498. UV: 252 (9200), 290 (7200). ${ }^{1} \mathrm{H}-\mathrm{NMR}$ (300 MHz): 2.89 $(2 \mathrm{H}, \mathrm{t}, J=8 \mathrm{~Hz}, \mathrm{C} 3-\mathrm{H}), 3.30(2 \mathrm{H}, \mathrm{t}, J=8 \mathrm{~Hz}, \mathrm{C} 2-\mathrm{H}), 3.75(3 \mathrm{H}, \mathrm{s}, \mathrm{MeO}), 4.13$ $\left(2 \mathrm{H}, \mathrm{s}, \mathrm{ArCH}_{2} \mathrm{~N}-\right), 5.94\left(2 \mathrm{H}, \mathrm{s}, \mathrm{OCH}_{2} \mathrm{O}\right), 6.10(1 \mathrm{H}, \mathrm{d}, J=2 \mathrm{~Hz}, \mathrm{C} 7-\mathrm{H}), 6.18$ $(1 \mathrm{H}, \mathrm{dd}, J=2,8 \mathrm{~Hz}, \mathrm{C} 5-\mathrm{H}), 6.7-6.9(3 \mathrm{H}, \mathrm{m}, \mathrm{ArH}), 6.96(1 \mathrm{H}, \mathrm{d}, J=8 \mathrm{~Hz}$, C4-H). ${ }^{13} \mathrm{C}-\mathrm{NMR}(75.0 \mathrm{MHz}): 27.7(\mathrm{t}), 53.1(\mathrm{t}), 53.9$ (t), 55.4 (q), 94.8 (d), 100.9 (t), 101.4 (d), 108.1 (d), 108.4 (d), 120.9 (d), 122.4 (s), 124.4 (d), 132.2 (s), 146.7 (s), 147.8 (s), 153.7 (s), 160.1 (s). LR-MS: m/z $283\left(\mathrm{M}^{+}\right)$, 135 (base peak). HR-MS $m / z\left(\mathrm{M}^{+}\right)$: Calcd for $\mathrm{C}_{17} \mathrm{H}_{17} \mathrm{NO}_{3}: 283.1209$. Found: 283.1212 .

Oxidation of 14 with $\mathrm{NaIO}_{4}$ To a solution of $14(0.1 \mathrm{~g}, 0.25 \mathrm{mmol})$ in acetone $(10 \mathrm{ml})$ was added a solution of $\mathrm{NaIO}_{4}(53 \mathrm{mg}, 0.25 \mathrm{mmol})$ in $\mathrm{H}_{2} \mathrm{O}$ $(5 \mathrm{ml})$, and the mixture was stirred at r.t. for $18 \mathrm{~h}$. After removal of the precipitated inorganic materials by filtration, the filtrate was concentrated in vacuo. The residue was extracted with $\mathrm{CHCl}_{3}$. The product was chromatographed and eluted with ethyl acetate/hexane $(1: 4)$ to give 6-methoxy1-(3,4-methylenedioxyphenyl)methyl-2,3-dioxo-2,3-dihydroindole (18) (32 $\mathrm{mg}, 42 \%)$ as reddish yellow crystals crystallized from $\mathrm{CHCl}_{3}-\mathrm{Et}_{2} \mathrm{O}, \mathrm{mp}$ 179-182 ${ }^{\circ} \mathrm{C}$. IR: 1736, 1717, 1626. UV: 263 (20300), 292 (6100), 312 (6700). ${ }^{1} \mathrm{H}-\mathrm{NMR}(300 \mathrm{MHz}): 3.85(3 \mathrm{H}, \mathrm{s}, \mathrm{MeO}), 4.79\left(2 \mathrm{H}, \mathrm{s}, \mathrm{ArCH}_{2} \mathrm{~N}-\right)$, $5.94\left(2 \mathrm{H}, \mathrm{s}, \mathrm{OCH}_{2} \mathrm{O}\right), 6.29(1 \mathrm{H}, \mathrm{d}, J=2 \mathrm{~Hz}, \mathrm{C} 7-\mathrm{H}), 6.53(1 \mathrm{H}, \mathrm{dd}, J=2,8 \mathrm{~Hz}$, C5-H), 6.7-6.9 (3H, m, ArH), $7.58(1 \mathrm{H}, \mathrm{d}, J=8 \mathrm{~Hz}, \mathrm{C} 4-\mathrm{H}) .{ }^{13} \mathrm{C}-\mathrm{NMR}$ $(75.0 \mathrm{MHz}): 43.7(\mathrm{t}), 56.0$ (q), 98.3 (d), $101.2(\mathrm{t}), 107.7$ (d), 107.8 (d), 108.4 (d), 111.3 (s), 120.9 (d), 128.0 (d), 128.4 (s), 147.4 (s), 148.2 (s), 153.0 (s), $160.0(\mathrm{~s}), 168.0(\mathrm{~s}), 180.5(\mathrm{~s})$. LR-MS: $m / z 311\left(\mathrm{M}^{+}\right), 176$ (base peak). HRMS $m / z\left(\mathrm{M}^{+}\right)$: Calcd for $\mathrm{C}_{17} \mathrm{H}_{13} \mathrm{NO}_{5}$ : 311.0794. Found: 311.0809. Anal. Calcd for $\mathrm{C}_{17} \mathrm{H}_{13} \mathrm{NO}_{5}$ : C, 65.59; H, 4.21; N, 4.50. Found: C, 65.40; H, 4.33; $\mathrm{N}, 4.37$.

Acknowledgements This work was supported by a Grant-in-Aid for Scientific Research (No. 11672115) from the Ministry of Education, Science, Sports and Culture of Japan.

\section{References and Notes}

1) Kennedy M., McKervey M., "Comprehensive Organic Chemistry," Vol. 7, ed. by Trost B., Fleming I., Pergamon, Oxford, 1991, pp. 193216.

2) Bates D. K.,Winters R. T., Picard J. A., J. Org. Chem., 57, 3094-3097 (1992).

3) a) Oikawa Y., Yonemitsu O., Tetrahedron Lett., 1972, 3393-3396; b) Idem, Tetrahedron, 30, 2653-2660 (1974); c) Tamura Y., Choi H.-D.,
Shindo H., Uenishi J., Ishibashi H., Tetrahedron Lett., 22, 81-84 (1981); d) Kataoka T., Tomoto A., Shimizu H., Hori M., J. Chem. Soc., Perkin Trans. 1, 1983, 2913-2919.

4) a) Bates D. K., J. Org. Chem., 42, 3453-3453 (1977); b) Tamura Y., Choi H. D., Maeda H., Ishibashi H., Tetrahedron Lett., 22, 13431344 (1981); c) Ishibashi H., Miki Y., Ikeda Y., Kiriyama A., Ikeda M., Chem. Pharm. Bull., 37, 3396-3398 (1989).

5) Padwa A, Gunn D. E., Jr., Osterhout M. H., Synthesis, 1997, 13531377.

6) Shinohara T., Toda J., Sano T., Chem. Pharm. Bull., 45, 813-819 (1997).

7) a) Shinohara T., Takeda A., Toda J., Terasawa N., Sano T., Heterocycles, 46, 555-565 (1997); b) Shinohara T., Takeda A., Toda J., Ueda Y., Kohno M., Sano, T., Chem. Pharm. Bull., 46, 918-927 (1998); c) Shinohara T., Takeda A., Toda J., Sano T., ibid., 46, 430- 433 (1998); d) Toda J., Niimura Y., Takeda K., Sano T., Tsuda Y., ibid., 46, 906912 (1998); e) Toda J., Niimura Y., Sano T., Tsuda Y., Heterocycles, 48, 1599-1607 (1998); f) Shinohara T., Takeda A., Toda J., Sano T., ibid., 48, 981—992 (1998); g) Toda J., Sakagami M., Sano T., Chem. Pharm. Bull., 47, 1269-1275 (1999); h) Toda J., Matsumoto S., Saitoh T., Sano T., ibid., 48, 91—98 (2000); i) Toda J., Ichikawa T., Saithoh T., Horiguchi Y., Sano T., Heterocycles, 53, 2009-2018 (2000); j) Toda J., Sonobe A., Ichikawa T., Saitoh T., Horiguchi Y., Sano T., ARKIVOC, 1, 165-180 (2000); $k$ ) Toda J., Sakagami M., Goan Y., Simakata M., Saitoh T., Horiguchi Y., Sano T., Chem. Pharm. Bull., 48, 1854-1861 (2000).

8) a) Tafel K. A., Bates D. K. J. Org. Chem., 57, 3676-3680 (1992); b) Bates D. K., Tafel K. A., ibid., 59, 8076-8080 (1994); c) Picard J. A., Chen S., Bates D. K. Heterocycles, 38, 1775-1789 (1994).

9) a) Bates D. K., Winter R. T., Sell B. A., J. Heterocycl. Chem., 23, 695-699 (1986); b) Bates D. K., Sell B. A., Picard J. A. Tetrahedron Lett., 28. 3535-3538 (1987); c) Wang H-M., Lin M.-C, Chen L-C., Heterocycles, 38, 1519-1526 (1994).

10) It has been reported that a stable sulfurane can be derived from nucleophilic attack on a sulfoxide sulfur atom. [Adzima L. J., Chiang C. C., Paul I. C., Martin J. C., J. Am. Chem. Soc., 100, 953-959 (1978)].

11) Typical papers dealing with stable sulfuranes are listed. [Korp J. D., Bernal I., Harris M. M., Patel P. K., Tetrahedron Lett., 1979, 40994100 (1979); Ogawa S., Matsunaga Y., Sato S., Ida I., Furukawa N., J. Chem. Soc., Chem. Commun. 1992, 1141-1142; Fowler J. E., Schaefer H. F., J. Am. Chem. Soc., 116, 9596-9601 (1994); Sato S., Furukawa N., Tetrahedron Lett., 36, 2803-2806 (1995)].

12) Baldwin J. E., J. Chem. Soc., Chem. Commum., 1976, 734-735; Baldwin J. E., Culting J., Dupont W., Kruse L., Silberman L., Thomas R. C., ibid., 1976, 736-738; Baldwin J. E., Thomas R. C., Kruse L. I., Silberman L., J. Org. Chem., 42, 3846-3852 (1977).

13) Tamura Y., Uenishi J. I., Maeda H., Choi H. D., Ishibashi H., Synthesis, 1981, 534-537. 